\title{
FORMATION OF A REVERSIBLE CELL IN THE ELECTROLYSIS OF MOLTEN SILVER NITRATE*
}

\author{
W. E. Triaca and A. J. Arvia \\ Instituto Superior de Investigaciones, Facultad de Química y Farmacia, and División Ingeniería \\ Química Facultad de Ciencias Fisicomatemáticas, Universidad Nacional de La Plata, La Plata, \\ Argentina
}

\begin{abstract}
In the electrolysis of pure molten silver nitrate with a silver cathode and a platinum anode
\end{abstract} at temperatures from 220 to $380^{\circ} \mathrm{C}$ a reversible cell is formed. When the system is electrolysed for a short time at a steady current density and then the current is interrupted, it tends to reach after a few seconds a reversible emf which is independent of the current density employed in the previous electrolysis. This emf is constant provided that the composition of the system is not altered. Short-circuiting the cell repeatedly always leads to the same emf.

The emf is related to the residual electrochemical cell formed during the electrolysis. The cell can be represented by the following scheme:

$$
\mathrm{Ag} / \mathrm{AgNO}_{3}(l) / \mathrm{NO}_{2}, \mathrm{NO}, \mathrm{O}_{2} / \mathrm{Pt} \text {. }
$$

The reversible reactions involved in the cell are

and

$$
\begin{aligned}
\mathrm{Ag}+\mathrm{NO}_{2}+\frac{1}{2} \mathrm{O}_{2} & \rightleftharpoons \mathrm{AgNO}_{3} \\
\mathrm{NO}+\frac{1}{2} \mathrm{O}_{2} & \rightleftharpoons \mathrm{NO}_{2} .
\end{aligned}
$$

The theoretical decomposition voltage of silver nitrate is coincident with the ones found experimentally, taking account of the actual concentrations of species involved in the reactions.

Résumé-Une cellule réversible se forme dans l'électrolyse de $\mathrm{AgNO}_{3}$ pur fondu avec cathode $\mathrm{Ag}$ et anode $\mathrm{Pt}$, à des températures de $220 \mathrm{à} 380^{\circ} \mathrm{C}$. Une courte électrolyse à courant stationnaire ensuite interrompu, suscite, après quelques secondes, une f.e.m. indépendante de la densité du courant d'électrolyse; elle se maintient constante, même après brefs court-circuits répétés. La cellule ainsi engendrée peut être représentée par

de réactions réversibles

$$
\mathrm{Ag} / \mathrm{AgNO}_{3}(I) / \mathrm{NO}_{2}, \mathrm{NO}, \mathrm{O}_{2} / \mathrm{Pt}
$$

$$
\left\{\begin{array}{l}
\mathrm{Ag}+\mathrm{NO}_{2}+\frac{1}{2} \mathrm{O}_{2} \rightleftarrows \mathrm{AgNO}_{3} \\
\mathrm{NO}+\frac{1}{2} \mathrm{O}_{2} \rightleftarrows \mathrm{NO}_{2} .
\end{array}\right.
$$

Il y a d'ailleurs accord avec la tension de décomposition théorique de $\mathrm{AgNO}_{3}$.

Zusammenfassung-Bei der Elektrolyse von reinem geschmolzenem Silbernitrat bilden eine Silberkathode und eine Platinanode eine reversible Zelle. Nach Stromunterbruch nimmt die Spannung rasch immer denselben Wert an unabhängig von der vorherigen Stromdichte. Die Spannung entspricht dem bei der Elektrolyse entstandenen Element

$$
\mathrm{Ag} / \mathrm{AgNO}_{8}(\mathrm{l}) / \mathrm{NO}_{2}, \mathrm{NO}, \mathrm{O}_{2} / \mathrm{Pt} \text {. }
$$

Die für verschiedene Temperaturen berechnete theoretische Zersetzungsspannung stimmt mit den experimentellen Werten überein.

\section{INTRODUCTION}

DURING a kinetic study of the electrochemical reactions occurring in the electrolysis of molten pure silver nitrate at different concentrations in molten potassium-nitratesodium-nitrate eutectic, ${ }^{1}$ employing a platinum anode and a silver cathode, the formation of a reversible cell has been observed. This cell is directly related to the theoretical decomposition voltage of the electrolyte and it must certainly be taken into account when polarization effects in these systems are considered.

* Manuscript received 16 October 1963. 
The galvanic cell formed is particularly interesting because of the behaviour of platinum electrodes in molten nitrates. When a platinum electrode is placed in the melt and becomes saturated with a nitrogen-dioxide-nitric-oxide-oxygen mixture in equilibrium, a reversible electrode involving nitrate ions is established.

\section{EXPERIMENTAL}

\section{Electrolytic cell and electrolyte}

The cells were made of Pyrex glass. They were round-bottom cylindrical cells whose different parts were assembled with standard tapered ground joints.

The cathode was a silver plate of the highest purity, $90 \mathrm{~cm}^{2}$. A $2-\mathrm{cm}^{2}$ platinum plate or wire were used indiscriminately as anodes. Both were sealed to glass tubing and the electrical contacts made in the usual way. A silver wire dipping into the clectrolyte was employed as a reference electrode.

Anode and reference electrodes were placed into different compartments made of Pyrex glass. Electrical continuity in the electrolyte was maintained by means of holes placed at their bottom.

The anodic compartment had an inlet for gases which were bubbled just in the region where the platinum electrode was placed. Gas outlets were at the top of the arrangement. The cell was placed in a thermostat and kept at a constant temperature to $\pm 1 \cdot 0^{\circ} \mathrm{C}$.

Silver nitrate, analytical reagent grade, previously recrystallized and dried, was employed as electrolyte.

\section{Electrical measurements}

A low voltage stabilized power pack and a conventional electrolysis circuit were employed. The latter was provided with a double interrupter synchronized to a potentiometric recorder to observe the evolution of electrode potential when electrolysis current was switched off after electrolysing the whole system at different current densities.

\section{RESULTS}

\section{The reversible potential}

When a current was passed through any of the different cells employed, at temperatures ranging from 220 to $380^{\circ} \mathrm{C}$, and then interrupted, a reversible potential was established between the electrodes. The reversible potential was independent of the current density used in the previous electrolysis and reached a steady value that lasted so long as the composition was not altered.

The reversibility of the residual cell was tested by short-circuiting the electrodes for a short time after the steady emf was reached. This operation could be repeated several times and, when opening the circuit, it was always observed that the emf immediately recovered its preliminary steady value. However, if purified oxygen or nitrogen was flowed through the anodic compartment, a decay of the emf was noticed and finally the reversible cell was destroyed.

When nitrogen was bubbled on the electrode at a low or a high rate, the emf decay was very rapid. But when oxygen was passed on the platinum electrode intermittently, a decay by steps was observed, which was according to the velocity of the gas bubbling on the platinum electrode. 
Figure 1 shows some effects described above. Data obtained under different conditions are found in Table 1, where $E$ is the cell emf at $t^{\circ} \mathrm{C}$ and $X$ is the mole fraction of each component.

\section{Temperature dependence of the emf}

The emf of the residual galvanic cell decreases when temperature increases. The temperature coefficient is $c a 3.0 \mathrm{mV} /{ }^{\circ} \mathrm{C}$ at the lower temperatures and $c a 2.0 \mathrm{mV} /{ }^{\circ} \mathrm{C}$ at the higher.

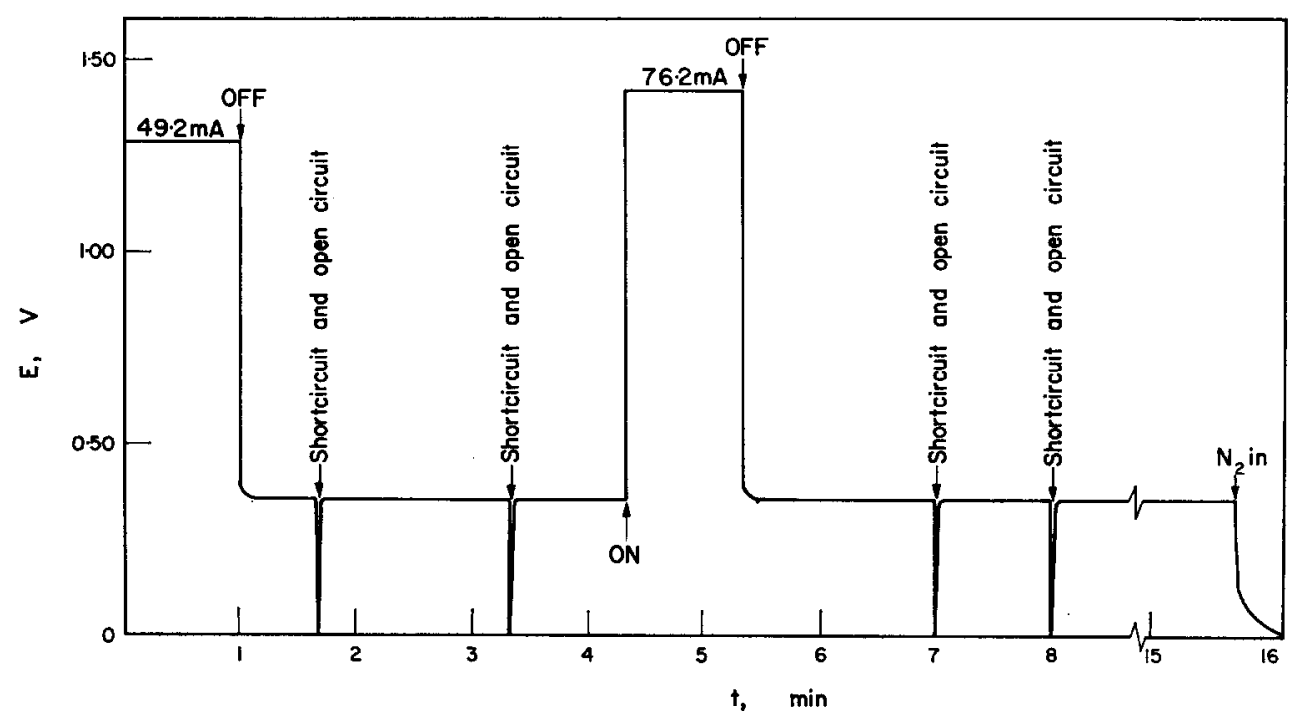

Fig. 1. Formation and test of the reversible cell. Electrolyte: molten pure silver nitrate. Temperature: $221^{\circ} \mathrm{C}$. Electrolysis current intensity as indicated.

Extrapolation of experimental data indicate that the emf of the galvanic cell is nil at $430 \pm 5^{\circ} \mathrm{C}$, which according to the literature, ${ }^{2}$ is the temperature where the spontaneous decomposition of the pure salt takes place.

The experimental results obtained by measuring the open circuit emf of the anode against the cathode of the cell after current interruption were perfectly coincident with the ones obtained by measuring the emf of the anode against the reference electrode under the same conditions. This result is consistent with the reversibility and reproducibility of both electrodes.

Considering that the temperature coefficient of the cell is large, the reproducibility attained by the cell is very good, as shown from the data of Table 1.

\section{Analysis of gases of the anodic compartment}

The gases formed during the electrolysis in the anodic compartment of the cell and in equilibrium when the current was interrupted have been identified and the composition of the mixture evaluated. At lower temperatures the mixture is mainly nitrogen dioxide and oxygen in the ratio of 2:1. At higher temperatures the existence of increasing quantities of nitric oxide has been verified. 
TABLE 1

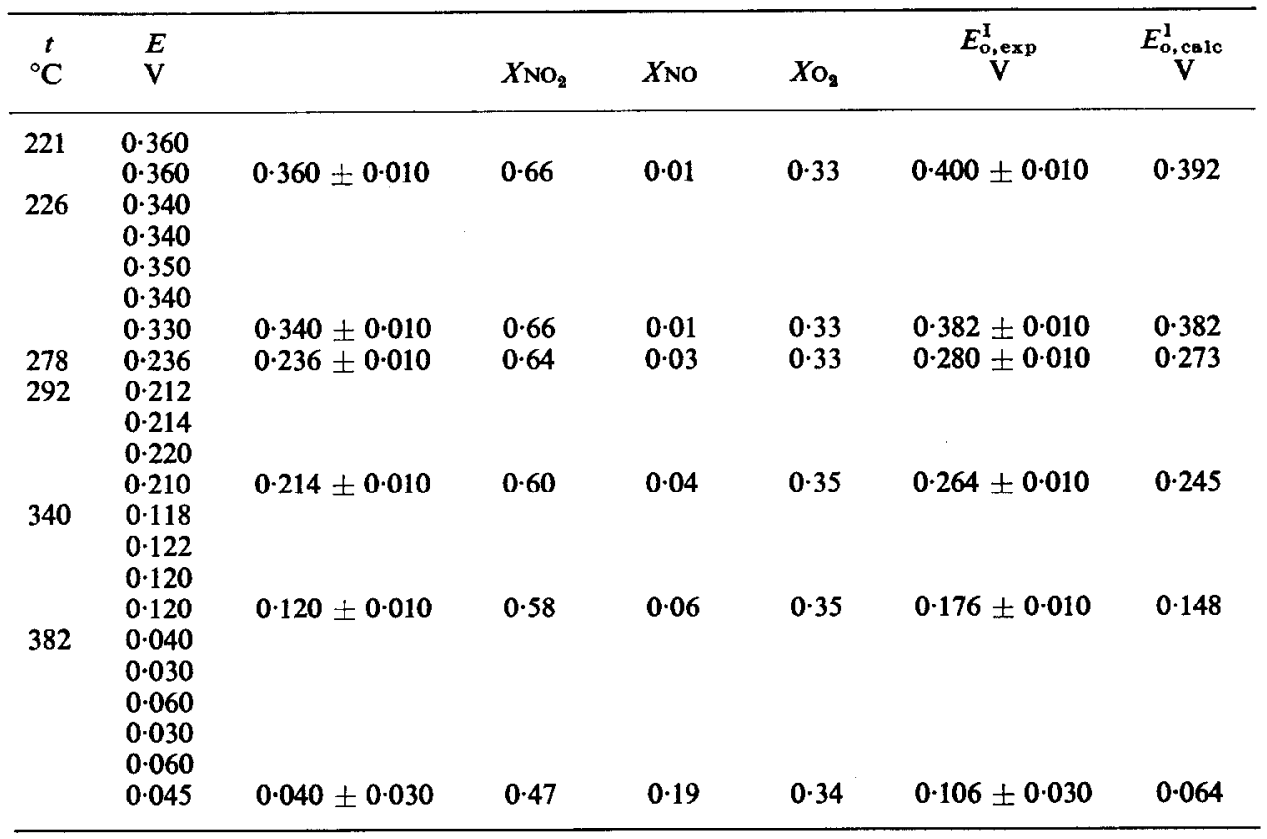

\section{INTERPRETATION AND DISCUSSION}

The experimental results indicate the existence of a reversible cell, without liquid junction, which can be represented

$$
\mathrm{Ag} / \mathrm{AgNO}_{3}(\mathrm{l}) / \mathrm{NO}_{2}, \mathrm{NO}, \mathrm{O}_{2} / \mathrm{Pt} \text {. }
$$

The reversible cell is formed by a silver/silver-ion electrode and a nitrogen dioxide, nitric oxide, oxygen/nitrate-ion electrode. Consequently the total equilibrium reactions involved in cell 1 can be written in one of the following ways,

$$
\mathrm{Ag}+\mathrm{NO}_{2}+\frac{1}{2} \mathrm{O}_{2} \rightleftharpoons \mathrm{AgNO}_{3}
$$

and

$$
\mathrm{NO}+\frac{1}{2} \mathrm{O}_{2} \rightleftharpoons \mathrm{NO}_{2},
$$

or

and

$$
\mathrm{Ag}+\mathrm{NO}+\mathrm{O}_{2} \rightleftharpoons \mathrm{AgNO}_{3}
$$

$$
\mathrm{NO}_{2} \rightleftharpoons \mathrm{NO}+\frac{1}{2} \mathrm{O}_{2}
$$

The theoretical decomposition voltage of silver nitrate, according to reactions (1a) and (2a), was obtained following two ways: (a) from the free energy of formation of each component involved in reactions (1a) and (2a) at temperature $T$, and (b) by using the more detailed thermodynamic calculation proposed by Hamer, Malmberg and Rubin $^{3}$ to evaluate the theoretical decomposition voltages of molten chlorides. For the latter the experimental equations for the heat capacities of each component must be known. Thermodynamic data required for the present case have been obtained from 
Kelley ${ }^{4}$ and from Circular 500 of the National Bureau of Standards. ${ }^{5}$ They are compiled in Table 2.

TABLE 2

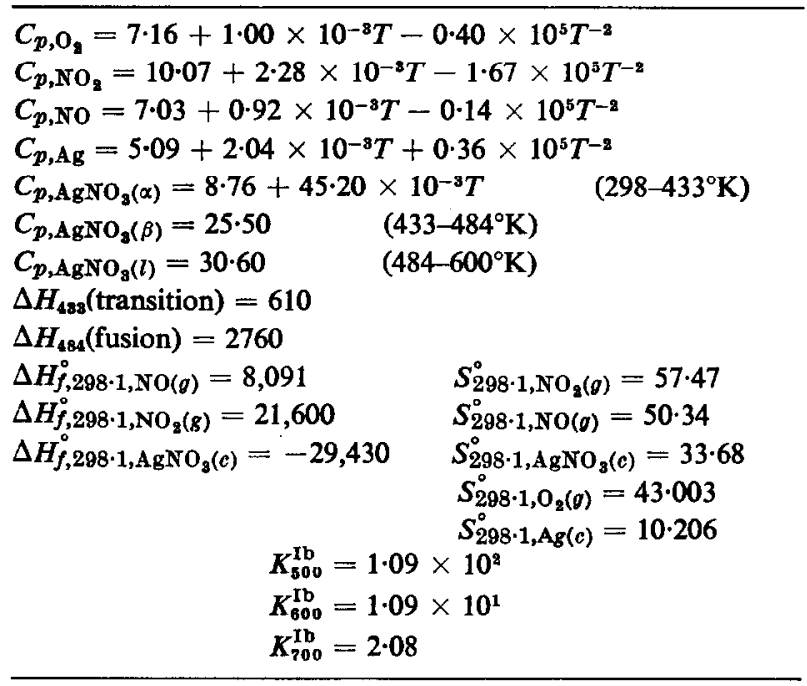

Calculations (a) and (b) give fairly coincident results but only those obtained by the latter method are reported here. The final equations for the standard potential of the electrodes of cell 1 are:

for reaction (1a), $E_{0}{ }^{\mathrm{I}}=1.645+5.143 \times 10^{-4} T \ln T-1.045 \times 10^{-7} T^{2}+3.274 / T-5.685 \times 10^{-3} T ;$

for reaction (2a), $E_{0}^{\text {II }}=2.245+4.908 \times 10^{-4} T \ln T-0.859 \times 10^{-7} T^{2}+0.390 / T-6.539 \times 10^{-3} T$.

The actual emf of cell 1 at temperature $T$ is represented by Nernst's equation, which can be expressed in terms of the standard potential given by (3) and (4), respectively, as follows:

$$
E=E_{0}{ }^{\mathrm{I}}-\frac{R T}{F} \ln a_{\mathrm{AgNO}_{\mathbf{3}}}+\frac{R T}{F} \ln a_{\mathrm{NO}_{2}}+\frac{R T}{F} \ln a_{\mathrm{O}_{2}}^{\frac{1}{2}}
$$

and

$$
E=E_{0}^{\mathrm{II}}-\frac{R T}{F} \ln a_{\mathrm{AgNO}_{3}}+\frac{R T}{F} \ln a_{\mathrm{NO}}+\frac{R T}{F} \ln a_{\mathrm{O}_{\mathrm{g}}}
$$

The application of both equations has been done in terms of the mole fractions of the components instead of their activities, and taking the activity of silver nitrate as equal to one. The composition of the gaseous mixture can be estimated because the equilibrium constant of reaction (1b) has been determined in the required range of temperature. ${ }^{6}$ 
As the equilibrium constant of reaction (2b) is small at temperatures below $300^{\circ} \mathrm{C}$, in this range (5) can be applied without appreciable error, ignoring the amount of nitrogen dioxide which is dissociated.

According to the last equations, if the composition of the gases is kept constant, the emf of the cell must change exclusively with the mole fraction of silver nitrate, suggesting the possibility of employing this system to determine the activity coefficient of silver ions dissolved in molten nitrates. Also, a decrease of the pressure of nitrogen dioxide or oxygen must produce a decrease of the emf. For nitrogen dioxide this effect was observed when the gas mixture was diluted with oxygen.

Theoretical and experimental values of the standard potential of cell 1 are compared in Table 1. The agreement between them is within the experimental errors of the present work.

Acknowledgement-The authors thank the Consejo Nacional de Investigaciones Cientificas y Técnicas de la República Argentina for financial support.

\section{REFERENCES}

1. W. E. Triaca and A. J. Arvia, in preparation.

2. P. Pascal, Traité de Chemie Minérale. Vol. VIII. Masson, Paris (1933).

3. J. W. Hamer, M. S. Malmberg and B. Rubin, J. Electrochem. Soc. 103, 8 (1956).

4. K. K. Kellex, Contribution to the Data on Theoretical Metallurgy-XIII. High Temperature Heat Content, Heat Capacity and Entropy Data for the Elements and Inorganic Compounds, Bull. 584, Bureau of Mines, USA (1960).

5. Selected Values of Chemical Thermodynamic Properties, National Bureau of Standards, Circular 500 (1952).

6. A. P. Altshuller, J. Phys. Chem. 61, 251 (1957). 